\title{
Indications of 5-Aminolevulinic Acid and Intraoperative MRI in Glioma Surgery: First Cases in Latin America in a Single Reference Center
}

\section{Indicações de ácido 5-aminolevulínico e ressonância magnética intraoperatória em cirurgia de gliomas: primeiros casos na América Latina em um único centro de referência}

\author{
Ricardo Ramina ${ }^{1}$ Erasmo Barros da Silva Júnior ${ }^{1}$ Felipe Constanzo ${ }^{1}$ Maurício Coelho Neto ${ }^{1}$ \\ ${ }^{1}$ Department of Neurosurgery, Instituto de Neurologia de Curitiba, \\ Curitiba, PR, Brazil \\ Arq Bras Neurocir 2018;37:88-94. \\ Address for correspondence Ricardo Ramina, PhD, Departamento de \\ Neurocirurgia, Instituto de Neurologia de Curitiba, Rua Jeremias \\ Maciel Perretto, 300, Curitiba, PR, Brazil, CEP: 81210310, Brazil \\ (e-mail: ramina@inc-neuro.com.br).
}

\begin{abstract}
Keywords

- 5-aminolevulinic acid

- brain cancer

- extent of resection

- glioma surgery

- intraoperative MRI

- glioblastoma
\end{abstract}

Resumo
Introduction The improvement on the extent of resection (EOR) of gliomas with the combination of 5-aminolevulinic acid (5-ALA) and intraoperative magnetic resonance imaging (iMRI) has been demonstrated in previous studies. We present our results with the combined use of 5-ALA and (iMRI) in the surgery of glial lesions.

Methods A total of 64 cases of patients with intracranial gliomas who underwent image-guided surgery using 5-ALA with and without (iMRI) were reviewed. All patients underwent an early postoperative MRI to evaluate the EOR. Other intra-operative techniques (awake surgery, electrophysiological stimulation and monitoring) were also performed according to the location of the tumor.

Results A total of 18 tumors did not show intraoperative 5-ALA fluorescence (according to the World Health Organization [WHO] classification of tumors, 2 WHO-grade I, 14 WHOgrade II, 1 WHO-grade III and 1 WHO-grade IV), and 46 tumors showed intraoperative 5-ALA fluorescence (3 WHO-grade II, 3 WHO-grade III, 40 WHO-grade IV). In 28 of the 46 5-ALA positive cases, a safe 5-ALA free resection was achieved. In the 5-ALA negative cases, the (iMRI) findings guided the EOR, and complete resection was achieved in 11 cases. Complete resection was opted out in gliomas infiltrating eloquent areas.

Conclusions The combined use of 5-ALA and IMRI showed improved results in glioma surgery, offering the safest maximal EOR. In the 5-ALA positive cases (mostly highgrade), fluorescence was a more useful tool. In the 5- ALA negative cases (mostly lowgrade), the (iMRI) was decisive to guide the EOR of the tumor.

Introdução Em estudos anteriores, foi demonstrado um aperfeiçoamento na extensão da resecção (EDR) de gliomas com a combinação de ácido 5-aminolevulínico (5-ALA) e a imagem de ressonância magnética intraoperatória (iRM). Nossos resultados são apresentados com o uso combinado de 5-ALA e (iRM) para a cirurgia de lesões gliais. received

April 2, 2018

accepted

June 5, 2018

published online

July 18, 2018
DOI https://doi.org/

10.1055/s-0038-1667182.

ISSN 0103-5355.
Copyright $(2018$ by Thieme Revinter

Publicações Ltda, Rio de Janeiro, Brazil
License terms

(c) $(1) \$$ 


Palavras-chave
- ácido 5-
aminolevulínico
- câncer de cérebro
- extensão da ressecção
- cirurgia de glioma
- ressonância
magnética
intraoperatória
- glioblastoma

Métodos Foram revisados 64 casos de gliomas intracranianos submetidos a cirurgia guiada por imagem por meio do uso de 5-ALA, com ou sem RMI. Todos os pacientes foram submetidos a ressonância magnética (RM) pré-operatória para a avaliação da EDR do tumor. Outras técnicas intraoperatórias (cirurgia acordado, estimulação eletrofisiológica e monitoração) também foram realizadas segundo a localização do tumor.

Resultados Um total de 18 tumores não apresentaram fluorescência com o 5-ALA (segundo a classificação de tumores da Organização Mundial de Saúde [OMS], 2 com grau OMS I, 14 com grau II, 1 com grau III e 1 com grau IV) e 46 tumores foram fluorescentes ( 3 com grau II, 3 com grau III, 40 com grau IV). Dos 46 casos positivos para 5-ALA, em 28 foi obtida uma ressecção segura e livre. Nos casos negativos para 5-ALA, os achados da (iRM) orientaram a EDR, e alcançou-se ressecção total em 11 casos. A ressecção total foi descartada em gliomas com infiltração em áreas eloquentes.

Conclusões O uso combinado de 5-ALA e (iRM) mostrou melhores resultados na cirurgia de gliomas, oferecendo uma EDR de segurança máxima. Nos casos positivos para 5-ALA (a maioria de grau alto), a fluorescência mostrou-se um instrumento mais útil. Nos casos negativos para 5-ALA (a maioria de grau baixo), a RMI foi decisiva para orientar a EDR tumoral.

\section{Introduction}

Extent of resection (EOR) is the most important prognostic factor in glioma surgery, with complete resection of contrastenhanced areas in high-grade gliomas (HGGs), and fluidattenuated inversion recovery (FLAIR)/T2-weighted in lowgrade gliomas (LGGs), as the primary goal to improve the outcome of the patient. ${ }^{1-3}$ Image-guided surgery is decisive to achieve these benefits, besides being considered a part of the standard care for patients with brain lesions. ${ }^{4}$ Intraoperative imaging modalities, particularly fluorescence with 5-aminolivulinic acid (5-ALA), 5,6 seem to improve the EOR, especially in HGGs. Also, the benefits of combining both tools seem relevant to improve overall survival (OS) and progression-free survival (PFS). ${ }^{5-9}$

We present the first cohort study of patients who underwent surgeries guided by a combination of 5-ALA and intraoperative magnetic resonance imaging (iMRI) for intracranial gliomas in Latin America. The indications, the safety profile and the EOR based on preoperative image findings were reviewed.

\section{Methods}

Between November 2015 and January 2018, 64 consecutive 5-ALA fluorescence-guided surgeries with or without iMRI were performed for intracranial gliomas, which were preoperatively evaluated with magnetic resonance imaging (MRI), perfusion magnetic resonance (MR), and MR spectroscopy, at Instituto de Neurologia de Curitiba (INC, in the Portuguese acronym), Brazil. In Brazil, 5-ALA as a pure salt is registered by the National Agency for Sanitary Vigilance (ANVISA, in the Portuguese acronym) under the number CAS 0957, 106-605 Brazilian Common Denomination (DCB, in the Portuguese acronym) and is provided by Carbolution Chemicals (St.
Ingbert, Germany). All patients signed an informed consent form, and the study was approved by the Institutional Ethical Review Board.

\section{Preoperative Evaluation}

Patients with intracranial masses are routinely evaluated with standard MRI as well as with MR perfusion and spectroscopy. The use of MR tractography and functional MRI was evaluated according to the location of the lesion. Age, sex and final histopathological diagnosis were considered for analysis. Pre- and postoperative Karnofsky performance scale (KPS) scores and follow-up status were also documented for later studies concerning the OS and the PFS.

\section{5-aminolivulinic Acid Protocol}

An oral dose of $20 \mathrm{mg} / \mathrm{kg}$ of 5-ALA was administered 3 hours before surgery, according to standardized protocols. ${ }^{10}$ After the administration, the patient is guarded from direct light for 24 hours to avoid porphyria-like skin reactions. Besides this, the preoperative care remained unchanged.

\section{Intraoperative Care}

Intraoperative image-guidance Brainlab Cranial Navigation (Brainlab ${ }^{\circledR}$ Kick ${ }^{\circledR}$ Purely Navigation, Munich, Germany) was used in all cases. Electrophysiological stimulation and monitoring or awake surgery were performed for tumors in eloquent areas. The Zeiss OPMI PENTERO 800 (Carl Zeiss, Oberkochen, Germany) with a special blue-light filter was used in all cases.

\section{Intraoperative Magnetic Resonance Imaging}

The iMRI exams were performed with a General Electric 1.5T Signa Excite MR (General Electric Inc., Boston, MA, US). The images were obtained according to the preoperative 
diagnosis: T1-, T2-, diffusion-weighted and FLAIR images for non-gadolinium-enhancing lesions (mostly low-grade tumors) and T1-, gadolinium-enhanced T1-, T2-, and diffusion-weighted images for gadolinium-enhancing lesions (mostly high-grade tumors).

\section{Classification of 5-aminolivulinic Acid Extent of Resection}

The fluorescence of the lesion was classified as 5-ALA positive (-Fig. 1) or 5-ALA negative. For positive cases, intraoperative tumor resection was classified as '5-ALA free' when all fluorescent areas were resected, or 'residual 5ALA' when residual fluorescent tissue was left to avoid postoperative deficits. An additional category of '5-ALA suspicious' was added for the cases in which the coloration at the end of the resection showed a weak fluorescence that the surgeon was not able to adequately evaluate as residual or as a mere infiltration of adjacent tissues.

\section{Classification of the Intraoperative Magnetic Resonance Imaging Extent of Resection}

For 5-ALA negative cases, and for some 5-ALA positive or suspicious cases, an IMRI exam was performed, and the image findings were classified as complete or partial resection by an experienced team of neuroradiologists (-Fig. 2).

\section{Postoperative Care}

A complete brain MRI protocol was performed in the first 24 hours after surgery.

\section{Results}

A total of 62 patients underwent 64 surgeries for intracranial glioma during the period covered by the present study. The sample was composed of 43 male and 21 female patients. The mean age was 51.25 years. All patients had a preoperative KPS $>70 \%$ at the time of the procedure. - Table 1 summarizes the 5-ALA and the IMRI EOR results.

\section{Classification Based on 5-aminolivulinic Acid Fluorescence}

18 of the 64 cases (28.1\%) were 5-ALA negative and 46 (71.9\%) were 5-ALA positive.

\section{5-aminolivulinic Acid Positive Cases and Extent of Resection}

Of the 46 cases 5-ALA positive cases, 18 (39.1\%) achieved 5ALA free resection; 18 (39.1\%) achieved residual 5-ALA status; and in 10 cases (21.7\%), the resection was classified as 5-ALA suspicious, and the patients underwent a further iMRI exam that confirmed complete tumor removal in all cases.

\section{5-aminolivulinic Acid Negative Cases and Extent of Resection Based on Intraoperative Magnetic Resonance Imaging}

The patients underwent iMRI exams, which showed complete resection in $11(61.1 \%)$ cases, and partial resection in 7 (38.9\%) cases.

There were no complications related to the method in our series. The cases of partial tumor resection were due to an infiltration of eloquent areas.

\section{Histopathological Findings and 5-aminolivulinic Acid Fluorescence}

Of the 18 5-ALA negative cases, there was 1 case of pilocytic astrocytoma and 1 of angiocentric glioma (both World Health Organization [WHO] grade I), 14 cases of WHO grade II gliomas, 1 case of WHO grade III glioma, and 1 case of WHO grade IV glioma. Of the 465 -ALA positive cases, there were 3 cases of WHO grade II gliomas, three cases of WHO grade III gliomas, and 40 cases of WHO grade IV gliomas. (- Table 2)

\section{Discussion}

The goal of surgical resection in brain gliomas is based on two principles: maximal tumor resection and functional preservation. Gross total resection (GTR) of HGGs and LGGs increases the median survival rate by $200 \%$ and $160 \%$ respectively, when compared of the survival rates of patients subjected to subtotal resection (STR). ${ }^{11,12}$ Gross total resection increases in $61 \%$ the likelihood of 1 year survival, and increases in $51 \%$ the likelihood of 12-month PFS when compared with STR in newly-diagnosed glioblastoma. ${ }^{13}$ Nonetheless, an STR of at least $70 \%$ has shown to improve the OS and seizure control, when seizures are present. ${ }^{11}$

Intraoperative magnetic resonance imaging emerged in the 1990 s, ${ }^{14-16}$ and has become an essential tool in glioma surgery, allowing neurosurgeons to evaluate in real time the EOR and the feasibility of continuing resection without

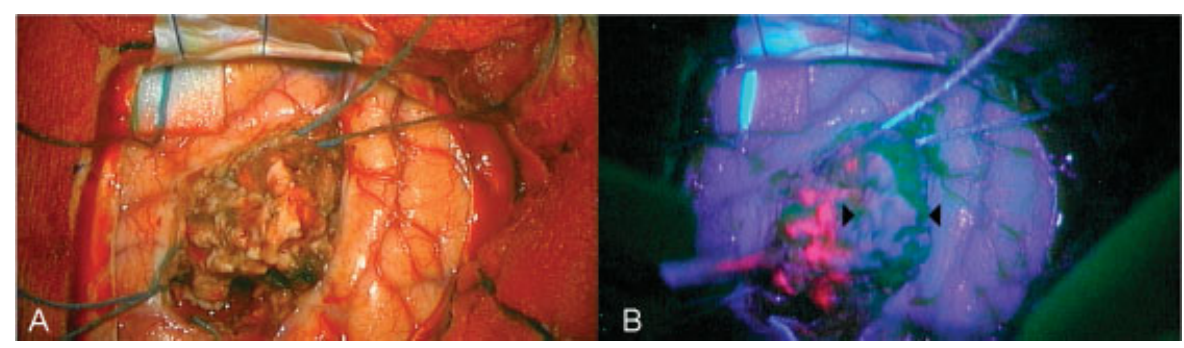

Fig. 1 Surgery of a high-grade glioma with 5-ALA using white-light microscopy (A) and blue-light filter (B). Note the red fluorescence of the lesion. Arrowheads showing weak pink fluorescence, which is suggestive of infiltration. 

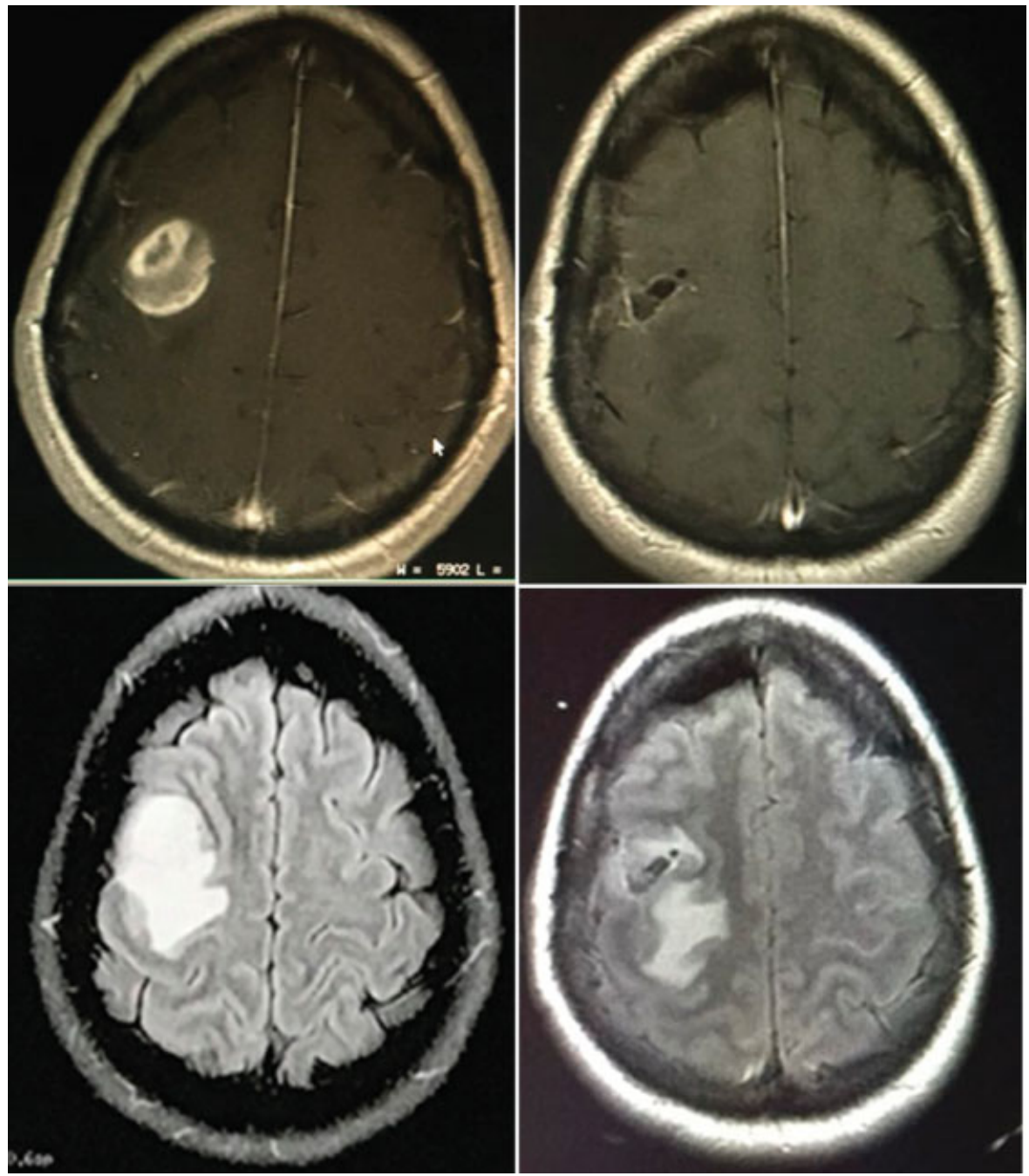

Fig. 2 Preoperative and intraoperative magnetic resonance imaging (MRI) of a right frontal glioblastoma, showing complete resection of the contrast-enhancing lesion, which correlated with an intraoperative 5-ALA-free resection.

disturbing eloquent areas. This has enabled an EOR of 99.78\% in tumors adjacent to eloquent areas, ${ }^{17}$ but the associated costs and logistics required for this procedure has limited its use in most centers around the world. ${ }^{18}$

Table 1 Classification and results of 5-aminolevulinic acid fluorescence

\begin{tabular}{|c|c|c|c|}
\hline & 5-ALA status & & iMRI \\
\hline \multirow[t]{10}{*}{ EOR } & \multirow{2}{*}{\multicolumn{2}{|c|}{ Negative: 18}} & Complete: 11 \\
\hline & & & Partial: 7 \\
\hline & \multirow[t]{8}{*}{ Positive: 46} & \multirow[t]{3}{*}{ Free: 18} & Complete: 7 \\
\hline & & & Partial: 0 \\
\hline & & & Not Performed: 11 \\
\hline & & \multirow[t]{3}{*}{ Residual: 18} & Complete: 0 \\
\hline & & & Partial: 5 \\
\hline & & & Not Performed: 13 \\
\hline & & \multirow[t]{2}{*}{ Suspicious: 10} & Complete: 10 \\
\hline & & & Partial: 0 \\
\hline
\end{tabular}

Abbreviations: 5-ALA, 5-aminolevulinic acid; EOR, extent of resection; iMRI, intraoperative magnetic resonance imaging
In 1998, the first series of intracranial tumors operated on with 5-ALA was reported. ${ }^{19,20}$ A total of 44 clinical studies using 5-ALA for glioma surgery have been published; these have demonstrated a GTR of $65 \%$ with 5-ALA compared to a GTR of $35 \%$ for the group operated on without fluorescence. ${ }^{21}$ In addition, an increase in the PFS of 3.8 months in the 5-ALA group was also achieved. ${ }^{21}$ Complete resections and improved PFS were more frequently achieved with 5-ALA when compared to white light-only resections, which have a higher risk of early transient neurological deterioration. ${ }^{22,23}$ For 5-ALA fluorescence and low-field iMRI, class I evidence derived both from randomized and controlled trials has demonstrated an

Table 2 Histopathological findings and 5-aminolevulinic acid

\begin{tabular}{|l|l|l|l|}
\hline & 5-ALA positive & 5-ALA negative & Total \\
\hline Grade I & 0 & 2 & 2 \\
\hline Grade II & 3 & 14 & 17 \\
\hline Grade III & 3 & 1 & 4 \\
\hline Grade IV & 40 & 1 & 41 \\
\hline
\end{tabular}

Abbreviation: 5-ALA, 5-aminolevulinic acid. 
92 Indications of 5-Aminolevulinic Acid and Intraoperative MRI in Glioma Surgery Ramina et al.

Table 3 Surgical information of 64 cases

\begin{tabular}{|c|c|c|c|c|c|c|}
\hline Sex, Age & Histopathological diagnosis & WHO grade & 5-ALA fluorescence & 5-ALA EOR & IMRI EOR & PO MRI EOR \\
\hline M, 73 & Glioblastoma & IV & Positive & Free & $C$ & $C$ \\
\hline $\mathrm{F}, 34$ & Diffuse astrocytoma & II & Positive & Residual & $\mathrm{N} / \mathrm{P}$ & $P$ \\
\hline $\mathrm{F}, 70$ & Glioblastoma & IV & Positive & Suspicious & $\mathrm{C}$ & C \\
\hline$F, 63$ & Glioblastoma & IV & Positive & Residual & $\mathrm{N} / \mathrm{P}$ & $P$ \\
\hline M, 35 & Glioblastoma & IV & Positive & Free & $\mathrm{C}$ & C \\
\hline M, 31 & Glioblastoma & IV & Positive & Residual & $P$ & $P$ \\
\hline $\mathrm{F}, 71$ & Glioblastoma & IV & Positive & Suspicious & C & $\mathrm{C}$ \\
\hline M, 74 & Glioblastoma & IV & Positive & Residual & $\mathrm{N} / \mathrm{P}$ & $\mathrm{P}$ \\
\hline M, 58 & Glioblastoma & IV & Positive & Free & $\mathrm{N} / \mathrm{P}$ & $\mathrm{C}$ \\
\hline M, 23 & Diffuse astrocytoma & II & Negative & $\mathrm{N} / \mathrm{A}$ & $C$ & C \\
\hline $\mathrm{M}, 17$ & Pilocytic astrocytoma & I & Negative & $\mathrm{N} / \mathrm{A}$ & $\mathrm{C}$ & $\mathrm{C}$ \\
\hline $\mathrm{F}, 26$ & Diffuse astrocytoma & II & Negative & $\mathrm{N} / \mathrm{A}$ & $P$ & $P$ \\
\hline M, 52 & Glioblastoma & IV & Negative & $\mathrm{N} / \mathrm{A}$ & $C$ & $\mathrm{C}$ \\
\hline$M, 73$ & Glioblastoma & IV & Positive & Suspicious & $\mathrm{C}$ & $C$ \\
\hline M, 58 & Glioblastoma & IV & Positive & Suspicious & $C$ & $C$ \\
\hline M, 69 & Diffuse astrocytoma & II & Positive & Free & $C$ & $\mathrm{C}$ \\
\hline M, 71 & Glioblastoma & IV & Positive & Suspicious & $C$ & $C$ \\
\hline M, 51 & Glioblastoma & IV & Positive & Suspicious & $C$ & $C$ \\
\hline M, 60 & Glioblastoma & IV & Positive & Residual & $\mathrm{N} / \mathrm{P}$ & $\mathrm{P}$ \\
\hline M, 35 & Diffuse astrocytoma & II & Negative & $\mathrm{N} / \mathrm{A}$ & $P$ & $P$ \\
\hline$F, 56$ & Anaplastic astrocytoma & III & Positive & Residual & $\mathrm{N} / \mathrm{P}$ & $P$ \\
\hline $\mathrm{F}, 30$ & Diffuse astrocytoma & II & Negative & $\mathrm{N} / \mathrm{A}$ & $C$ & $\mathrm{C}$ \\
\hline $\mathrm{M}, 73$ & Glioblastoma & IV & Positive & Free & $\mathrm{N} / \mathrm{P}$ & $\mathrm{C}$ \\
\hline$F, 58$ & Glioblastoma & IV & Positive & Free & $\mathrm{N} / \mathrm{P}$ & C \\
\hline M, 51 & Glioblastoma & IV & Positive & Free & $\mathrm{N} / \mathrm{P}$ & $C$ \\
\hline M, 52 & Glioblastoma & IV & Positive & Residual & $\mathrm{N} / \mathrm{P}$ & $\mathrm{P}$ \\
\hline M, 59 & Anaplastic oligodendroglioma & III & Positive & Residual & $\mathrm{N} / \mathrm{P}$ & $P$ \\
\hline M, 57 & Glioblastoma & IV & Positive & Residual & $P$ & $\mathrm{P}$ \\
\hline $\mathrm{F}, 46$ & Glioblastoma & IV & Positive & Suspicious & C & C \\
\hline$M, 52$ & Glioblastoma & IV & Positive & Residual & $P$ & $P$ \\
\hline M, 31 & Glioblastoma & IV & Positive & Residual & $\mathrm{P}$ & $\mathrm{P}$ \\
\hline $\mathrm{F}, 65$ & Glioblastoma & IV & Positive & Free & $\mathrm{N} / \mathrm{P}$ & $C$ \\
\hline M, 50 & Oligodendroglioma & II & Negative & $\mathrm{N} / \mathrm{A}$ & $\mathrm{C}$ & $\mathrm{C}$ \\
\hline M, 50 & Oligodendroglioma & II & Negative & $\mathrm{N} / \mathrm{A}$ & C & C \\
\hline $\mathrm{F}, 74$ & Glioblastoma & IV & Positive & Free & $\mathrm{N} / \mathrm{P}$ & $C$ \\
\hline $\mathrm{M}, 32$ & Diffuse astrocytoma & II & Positive & Free & $N / P$ & C \\
\hline M, 69 & Diffuse astrocytoma & II & Negative & N/A & $P$ & $P$ \\
\hline M, 45 & Glioblastoma & IV & Positive & Free & $C$ & $\mathrm{C}$ \\
\hline $\mathrm{F}, 71$ & Glioblastoma & IV & Positive & Residual & $\mathrm{N} / \mathrm{P}$ & $\mathrm{P}$ \\
\hline$F, 39$ & $\begin{array}{l}\text { Glioma with astroblastoma- } \\
\text { like components }\end{array}$ & IV & Positive & Free & $\mathrm{N} / \mathrm{P}$ & $C$ \\
\hline M, 52 & Anaplastic astrocytoma & III & Negative & $\mathrm{N} / \mathrm{A}$ & $C$ & C \\
\hline M, 62 & Glioblastoma & IV & Positive & Suspicious & $C$ & C \\
\hline M, 38 & Glioblastoma & IV & Positive & Residual & $\mathrm{N} / \mathrm{P}$ & $P$ \\
\hline
\end{tabular}


Table 3 (Continued)

\begin{tabular}{|c|c|c|c|c|c|c|}
\hline Sex, Age & Histopathological diagnosis & WHO grade & 5-ALA fluorescence & 5-ALA EOR & IMRI EOR & PO MRI EOR \\
\hline$F, 56$ & Glioblastoma & IV & Positive & Residual & $\mathrm{N} / \mathrm{P}$ & $P$ \\
\hline M, 32 & Diffuse astrocytoma & II & Negative & $\mathrm{N} / \mathrm{A}$ & C & C \\
\hline$M, 23$ & Angiocentric glioma & 1 & Negative & $\mathrm{N} / \mathrm{A}$ & c & C \\
\hline$M, 43$ & Diffuse astrocytoma & II & Negative & $\mathrm{N} / \mathrm{A}$ & $\mathrm{P}$ & $P$ \\
\hline$M, 53$ & Oligodendroglioma & II & Negative & $\mathrm{N} / \mathrm{A}$ & $P$ & $P$ \\
\hline$F, 53$ & Oligodendroglioma & II & Negative & $\mathrm{N} / \mathrm{A}$ & $P$ & $P$ \\
\hline M, 64 & Oligodendroglioma & II & Negative & $\mathrm{N} / \mathrm{A}$ & C & C \\
\hline$F, 55$ & Glioblastoma & IV & Positive & Suspicious & C & $\mathrm{C}$ \\
\hline M, 35 & Diffuse astrocytoma & II & Negative & $\mathrm{N} / \mathrm{A}$ & $P$ & $P$ \\
\hline $\mathrm{M}, 40$ & Anaplastic oligodendroglioma & III & Positive & Free & $\mathrm{N} / \mathrm{P}$ & C \\
\hline$F, 54$ & Glioblastoma & IV & Positive & Suspicious & C & C \\
\hline$M, 46$ & Glioblastoma & IV & Positive & Free & c & c \\
\hline M, 51 & Glioblastoma & IV & Positive & Residual & $\mathrm{N} / \mathrm{P}$ & $P$ \\
\hline M, 49 & Glioblastoma & IV & Positive & Residual & $\mathrm{N} / \mathrm{P}$ & $\mathrm{P}$ \\
\hline$F, 39$ & $\begin{array}{l}\text { Glioma with astroblastoma- } \\
\text { like components }\end{array}$ & IV & Positive & Residual & $\mathrm{N} / \mathrm{P}$ & $P$ \\
\hline$M, 54$ & Glioblastoma & IV & Positive & Free & c & c \\
\hline M, 75 & Glioblastoma & IV & Positive & Free & $\mathrm{N} / \mathrm{P}$ & C \\
\hline F, 29 & Diffuse astrocytoma & II & Negative & $\mathrm{N} / \mathrm{A}$ & $C$ & C \\
\hline$F, 73$ & Glioblastoma & IV & Positive & Residual & $P$ & $\mathrm{P}$ \\
\hline$M, 41$ & Glioblastoma & IV & Positive & Free & $\mathrm{N} / \mathrm{P}$ & C \\
\hline M, 51 & Glioblastoma & IV & Positive & Free & $\mathrm{N} / \mathrm{P}$ & $\mathrm{C}$ \\
\hline
\end{tabular}

Abbreviations: 5-ALA, 5-aminolevulinic acid; C, complete removal; EOR, extent of resection; F, female; iMRI, intraoperative magnetic resonance imaging; M,male; iRM, magnetic resonance imaging; N/P, not performed; N/A, not applicable; P, partial removal; PO, postoperative; WHO, World Health Organization.

increase in the EOR. ${ }^{23,24}$ However, some authors have shown conflicting results. Hauser et al, ${ }^{7}$ using both iMRI and 5-ALA, found contrast-enhancement after complete resection of fluorescent tissue in $91.7 \%$ of the patients, and the use of 5-ALA did not improve the OS or the PFS. Tsugu et $\mathrm{al}^{5}$ reported a similar EOR on postoperative 1.5-T MRI between the groups of fluorescence only (91.8\%) versus fluorescence plus subsequent iMRI (92.6\%). Eyüpoglu et $\mathrm{al}^{25}$ reported an improved EOR by combining 5-ALA and iMRI in malignant gliomas close to eloquent areas, with residual tumors observed on iMRI exams in $32.4 \%$ of the patients upon completion of 5-ALA-guided resection. They proposed that the missing fluorescent areas were due to layers of overlying, non-fluorescent tissue. Coburger et $\mathrm{a}^{26}$ reported a significant advantage of 5-ALA fluorescence over iMRI, with higher rates of sensitivity (91\% for 5-ALA versus $66 \%$ for iMRI) and specificity ( $80 \%$ for 5 -ALA versus $60 \%$ for iMRI).

In the present article, 5-ALA was used in all cases ( - Table 3 ), but its indication can be based on preoperative MRI (including advanced MRI techniques), suggesting an HGG. Tumors without contrast enhancement and without 'hot areas' on MRI perfusion, suggesting a low-grade lesion, can be chosen for iMRI only. The results of the 5-ALA response and of the histopathological findings in our series are in line with the literature.
In cases in which 5-ALA was negative, iMRI was immediately used to evaluate the EOR. Moreover, the 'residual 5-ALA' patients who underwent an iMRI exam had an early corroboration of residual tumor, which was directly related with the non-resected strong red fluorescent tissue. Zones with weak fluorescence (pink), although representing a tissue-infiltrating tumor, do not necessarily correspond to a residual lesion in the iMRI evaluation. In our series, the choice for iMRI in 5-ALA positive cases was based on the suspicion of these areas. ${ }^{27-30}$ As discussed before, both methods, 5-ALA and iMRI, can work in synergy especially to clarify dubious transoperative findings. The choice of one of the methods may be based on preoperative image findings and costs limitations. The OS and the PFS of our series will be the subject of a later publication.

\section{Conclusion}

In glioma surgery, 5-ALA fluorescence and iMRI are essential tools for safe tumor removal, increasing GTR and, possibly, resulting in an improvement in the PFS. For 5-ALA positive tumors, mostly HGGs, fluorescence could guide the EOR, and the iMRI could work in synergy if the neurosurgical team considers it necessary. On the other hand, 5-ALA negative tumors, mostly LGGs, directly benefited from the use of iMRI 
to improve the EOR. Both methods can work in harmony and with a safe and practical learning curve for the neurosurgical team.

\section{Conflicts of Interest}

The authors have no conflicts of interest to disclose.

\section{References}

1 Lacroix M, Abi-Said D, Fourney DR, et al. A multivariate analysis of 416 patients with glioblastoma multiforme: prognosis, extent of resection, and survival. J Neurosurg 2001;95(02):190-198. Doi: 10.3171/jns.2001.95.2.0190

2 Bloch O, Han SJ, Cha S, et al. Impact of extent of resection for recurrent glioblastoma on overall survival: clinical article. J Neurosurg 2012; 117(06):1032-1038. Doi: 10.3171/2012.9.JNS12504

3 Eseonu CI, ReFaey K, Garcia O, Raghuraman G, Quinones-Hinojosa A. Volumetric analysis of extent of resection, survival, and surgical outcomes for insular gliomas. World Neurosurg 2017;103:265-274. Doi: 10.1016/j.wneu.2017.04.002

4 Barone DG, Lawrie TA, Hart MG. Image guided surgery for the resection of brain tumours. Cochrane Database Syst Rev 2014; (01):CD009685. Doi: 10.1002/14651858.CD009685.pub2

5 Tsugu A, Ishizaka H, Mizokami Y, et al. Impact of the combination of 5aminolevulinic acid-induced fluorescence with intraoperative magnetic resonance imaging-guided surgery for glioma. World Neurosurg 2011;76(1-2):120-127. Doi: 10.1016/j.wneu.2011.02.005

6 Gessler F, Forster MT, Duetzmann S, et al. Combination of Intraoperative Magnetic Resonance Imaging and Intraoperative Fluorescence to Enhance the Resection of Contrast Enhancing Gliomas. Neurosurgery 2015;77(01):16-22, discussion 22. Doi: 10.1227/ NEU.0000000000000729

7 Hauser SB, Kockro RA, Actor B, Sarnthein J, Bernays RL. Combining 5-Aminolevulinic Acid Fluorescence and Intraoperative Magnetic Resonance Imaging in Glioblastoma Surgery: A Histology-Based Evaluation. Neurosurgery 2016;78(04):475-483. Doi: 10.1227/ NEU.0000000000001035

8 Quick-Weller J, Lescher S, Forster MT, Konczalla J, Seifert V, Senft C. Combination of 5-ALA and iMRI in re-resection of recurrent glioblastoma. Br J Neurosurg 2016;30(03):313-317. Doi: 10.3109/ 02688697.2015.1119242

9 Schatlo B, Fandino J, Smoll NR, et al. Outcomes after combined use of intraoperative MRI and 5-aminolevulinic acid in high-grade glioma surgery. Neuro-oncol 2015;17(12):1560-1567. Doi: 10.1093/neuonc/ nov049

10 Stummer W, Stepp H, Wiestler OD, Pichlmeier U. Randomized, Prospective Double-Blinded Study Comparing 3 Different Doses of 5-Aminolevulinic Acid for Fluorescence-Guided Resections of Malignant Gliomas. Neurosurgery 2017;81(02):230-239. Doi: 10.1093/neuros/nyx074

11 Chaichana KL, Jusue-Torres I, Navarro-Ramirez R, et al. Establishing percent resection and residual volume thresholds affecting survival and recurrence for patients with newly diagnosed intracranial glioblastoma. Neuro-oncol 2014;16(01):113-122. Doi: 10.1093/neuonc/not137

12 McGirt MJ, Chaichana KL, Gathinji M, et al. Independent association of extent of resection with survival in patients with malignant brain astrocytoma. J Neurosurg 2009;110(01):156-162. Doi: 10.3171/2008.4.17536

13 Brown TJ, Brennan MC, Li M, et al. Association of the extent of resection with survival in glioblastoma: A systematic review and meta-analysis. JAMA Oncol 2016;2(11):1460-1469. Doi: 10.1001/ jamaoncol.2016.1373

14 Alexander E III, Moriarty TM, Kikinis R, Jolesz FA. Innovations in minimalism: intraoperative MRI. Clin Neurosurg 1996;43:338-352

15 Black PM, Moriarty T, Alexander E III, et al. Development and implementation of intraoperative magnetic resonance imaging and its neurosurgical applications. Neurosurgery 1997;41(04):831-842, discussion 842-845. Doi: 10.1097/00006123-199710000-00013

16 Nimsky C, Ganslandt O, Kober H, Buchfelder M, Fahlbusch R. Intraoperative magnetic resonance imaging combined with neuronavigation: a new concept. Neurosurgery 2001;48(05):1082-1089, discussion 1089-1091. Doi: 10.1097/00006123-200105000-0002

17 Reyns N, Leroy HA, Delmaire C, Derre B, Le-Rhun E, Lejeune JP. Intraoperative MRI for the management of brain lesions adjacent to eloquent areas. Neurochirurgie 2017;63(03):181-188. Doi: 10.1016/j.neuchi.2016.12.006

18 Ramina R, Coelho Neto M, Giacomelli A, et al. Optimizing costs of intraoperative magnetic resonance imaging. A series of 29 glioma cases. Acta Neurochir (Wien) 2010;152(01):27-33. Doi: 10.1007/ s00701-009-0430-2

19 Stummer W, Stepp H, Möller G, Ehrhardt A, Leonhard M, Reulen HJ. Technical principles for protoporphyrin-IX-fluorescence guided microsurgical resection of malignant glioma tissue. Acta Neurochir (Wien) 1998;140(10):995-1000

20 Stummer W, Stocker S, Wagner S, et al. Intraoperative detection of malignant gliomas by 5 -aminolevulinic acid-induced porphyrin fluorescence. Neurosurgery 1998;42(03):518-525, discussion 525-526

21 Senders JT, Muskens IS, Schnoor R, et al. Agents for fluorescenceguided glioma surgery: a systematic review of preclinical and clinical results. Acta Neurochir (Wien) 2017;159(01):151-167. Doi: 10.1007/s00701-016-3028-5

22 Stummer W, Tonn JC, Mehdorn HM, et al; ALA-Glioma Study Group. Counterbalancing risks and gains from extended resections in malignant glioma surgery: a supplemental analysis from the randomized 5-aminolevulinic acid glioma resection study. Clinical article. J Neurosurg 2011;114(03):613-623. Doi: 10.3171/2010.3. JNS097

23 Stummer W, Pichlmeier U, Meinel T, Wiestler OD, Zanella F, Reulen HJ; ALA-Glioma Study Group. Fluorescence-guided surgery with 5aminolevulinic acid for resection of malignant glioma: a randomised controlled multicentre phase III trial. Lancet Oncol 2006;7 (05):392-401

24 Senft C, Bink A, Franz K, Vatter H, Gasser T, Seifert V. Intraoperative MRI guidance and extent of resection in glioma surgery: a randomised, controlled trial. Lancet Oncol 2011;12(11):997-1003. Doi: 10.1016/S1470-2045(11)70196-6

25 Eyüpoglu IY, Hore N, Savaskan NE, et al. Improving the extent of malignant glioma resection by dual intraoperative visualization approach. PLoS One 2012;7(09):e44885. Doi: 10.1371/journal. pone. 0044885

26 Coburger J, Engelke J, Scheuerle A, et al. Tumor detection with 5aminolevulinic acid fluorescence and Gd-DTPA-enhanced intraoperative MRI at the border of contrast-enhancing lesions: a prospective study based on histopathological assessment. Neurosurg Focus 2014;36(02):E3. Doi: 10.3171/2013.11.FOCUS13463

27 Stummer W, Novotny A, Stepp H, Goetz C, Bise K, Reulen HJ. Fluorescence-guided resection of glioblastoma multiforme by using 5-aminolevulinic acid-induced porphyrins: a prospective study in 52 consecutive patients. J Neurosurg 2000;93(06): 1003-1013. Doi: $10.3171 /$ jns.2000.93.6.1003

28 Panciani PP, Fontanella M, Schatlo B, et al. Fluorescence and image guided resection in high grade glioma. Clin Neurol Neurosurg 2012;114(01):37-41. Doi: 10.1016/j.clineuro.2011.09.001

29 Díez Valle R, Tejada Solis S, Idoate Gastearena MA, García de Eulate R, Domínguez Echávarri P, Aristu Mendiroz J. Surgery guided by 5aminolevulinic fluorescence in glioblastoma: volumetric analysis of extent of resection in single-center experience. J Neurooncol 2011; 102(01):105-113. Doi: 10.1007/s11060-010-0296-4

30 Roberts DW, Valdés PA, Harris BT, et al. Coregistered fluorescenceenhanced tumor resection of malignant glioma: relationships between $\delta$-aminolevulinic acid-induced protoporphyrin IX fluorescence, magnetic resonance imaging enhancement, and neuropathological parameters. Clinical article. J Neurosurg 2011;114(03): 595-603. Doi: 10.3171/2010.2.JNS091322 